\title{
Filozoficzne ujęcie kultury politycznej
}

DOI 10.35757/CIV.2016.18.05

Źródłowe ujęcie kultury politycznej zaprezentowali dwaj znani badacze: Gabriel Almond i Sidney Verba. Opisujac przeobrażenia kultury politycznej zachodzace po II wojnie światowej, stwierdzili oni, że w latach siedemdziesiątych można było zaobserwować wytwarzanie się na świecie takiej kultury, która cechowały unifikacja oraz partycypacja. Teza tekstu jest twierdzenie, że obserwujemy powrót kategorii kultury politycznej, która coraz częściej jest rozumiana jako obszar samowolnie podejmowanych praktyk, stanowiących istotna przestrzeń nie tyle władzy czy prawa, ile częściowo samorzutnie kształtowanych zachowań. Za przykład tej tendencji może służyć zwrot, jaki w latach dziewięćdziesiątych dokonał się w myśli Johna Rawlsa, który początkowo prowadził studia nad pojęciem sprawiedliwości, a następnie przeszedł do konstrukcji modelu liberalnej kultury politycznej. Także inni współcześni badacze obecnie wskazuja, że kluczem do wytworzenia się instytucjonalnych form liberalnej demokracji jest wykształcenie właściwej dla tej formy ustrojowej kultury politycznej. Różnica pomiędzy współczesnym rozumieniem „kultury politycznej” a jej ujęciem zaprezentowanym przez Almonda i Verbę w latach siedemdziesiątych polega więc na tym, że wówczas kultura polityczna traktowana była socjologicznie, jako historycznie ukształtowany zbiór praktyk i postaw, które można badać przy użyciu narzędzi ilościowych

Agnieszka Nogal - doktor habilitowany, profesor w Instytucie Filozofii Uniwersytetu Warszawskiego. 
i jakościowych. Tymczasem współcześnie kultura polityczna stała się przedmiotem badań z zakresu filozofii polityki. Coraz częśsciej jest ujmowana normatywnie, jako debata wokół pozytywnego wzorca postaw obywatelskich, które winny być kształtowane $\mathrm{w}$ procesie edukacji.

Pojęcie „kultura” jest niezwykle pojemne. Właściwie może oznaczać niemal wszystko ${ }^{1}$. W związku $z$ tym niełatwo je zdefiniować, co najwyżej da się wskazać pewne elementy znaczeniowe, które bywaja z nim wiąane. Po pierwsze, od czasów oświecenia kulturę przeciwstawia się temu, co naturalne. Kultura zatem odnosi się do świata wytworzonego przez człowieka, gdzie zarówno przestrzeń, jak i czas zostały zasadniczo przekształcone. Przekształcona przestrzeń to ludzkie wytwory, przedmioty, a więc cała sfera techniki i sztuki, a także jest nią sama organizacja owej przestrzeni. Przekształcony czas natomiast wskazuje $z$ jednej strony na aktualnie obowiazujace tendencje, prądy czy mody, a $z$ drugiej - zbiór instytucji obejmujacych wszelkie praktyki społeczne, takie jak na przykład edukacja, polityka, dostęp do wytwarzania dóbr, możliwość ich recepcji oraz sfera idei i pojęć, za pomoca których dobra oraz praktyki sa interpretowane przez ich twórców i odbiorców. Czas w tym kontekście wskazuje także na historyczność kultury. O ile naturalny świat składa się $\mathrm{z}$ cykli życiowych, o tyle świat kultury wyznacza liniowy ciag pojawiających się wytworów, ukazując kolejność ich następowania. Kultura jest więc sumą materialnych wytworów wraz $z$ ich społecznymi i dyskursywnymi znaczeniami (poziom empiryczny) oraz pewna uwewnętrzniona przez jej uczestników dyspozycja do rozumienia tych wytworów i praktyk w określony sposób, czyli nadawania im pewnych znaczeń (poziom interpretacji). Oba wymiary maja historyczny i zmienny charakter.

Badanie kultury na poziomie empirycznym wymaga analizy jej jednostkowych wytworów oraz ich kontekstu przestrzennego i czasowego, a także sensów kształtujących ów kontekst. Na po-

1 J.G. Herder: Myśli o filozofii dziejów, t. I, przekład J. Gałecki, Państwowe Wydawnictwo Naukowe, Warszawa 1962, s. 4. 
ziomie interpretacji zaś polega na odsłanianiu często ukrytych i nieświadomie przyjmowanych przesłanek, determinujacych dyspozycje do rozumienia wytworów kultury zarówno materialnych, jak i instytucjonalnych. Interpretacja zakłada bowiem - otwarcie bądź nie - określone normy, $z$ perspektywy których dobra te są interpretowane, hierarchizowane, akceptowane bądź odrzucane. I dlatego płaszczyznę interpretacji można także określić mianem poziomu normatywnego. Ów poziom normatywny staje się kluczem do historii, gdyż wskazuje powody, dla których jedne dobra zostaja wyparte przez inne, podobnie jak jedne praktyki zastapione drugimi. O ile więc samo uczestnictwo w kulturze może opierać się na prostym użytkowaniu dóbr, powielaniu wzorców i podtrzymywaniu wytworzonych kulturowo kodów oraz znaczeń, o tyle wszelkie zmiany wymagaja wzięcia pod uwagę także wymiaru normatywnego, analizy uzasadnień i argumentacji na rzecz takich, a nie innych rozwiazań ${ }^{2}$.

Kultura jest przy tym, po pierwsze, wspólnotowa, po drugie zaś, ma charakter historycznie zmienny. Najważniejszymi elementami kultury są: wartości, rytuały, symbole, bohaterowie i wzorce zachowań $^{3}$. Kultura jest przejmowana i modyfikowana przez kolejne pokolenia $\mathrm{w}$ drodze socjalizacji. Od natury kulturę odróżnia historyczna zmienność, od osobowości - wspólnotowy, a nie indywidualny charakter. Kulturę całościowo najczęściej analizuje się na płaszczyźnie narodowej lub cywilizacyjnej. Posługujemy się także terminami subkultura i kontrkultura w odniesieniu do pewnych grup społeczeństwa.

Ze względu na konieczność dookreślenia pojęcia kultury można wyróżnić pewne sfery jej funkcjonowania, determinujące jej sens: społeczną, publiczna, obywatelska i polityczną.

Po pierwsze, kultura ma wymiar społeczny. Oznacza to, że łączy jednostki ludzkie w związki i stowarzyszenia. Sa one często

2 A. Jabłoński: Kultura polityczna i jej przemiany, w: A. Jabłoński, L. Sobkowiak (red.): Studia z teorii polityki, t. I, Wydawnictwo Uniwersytetu Wrocławskiego, Wrocław 1998, s. 177. 3 Ibidem. 
zhierarchizowane i ekskluzywne, a powstaja na skutek rozmaitej aktywności ludzi: zawodowej, ekonomicznej, wyznaniowej czy innej. Chodzi zatem o takie zrzeszenia i zwiazki, jak Kościoły, organizacje społeczne, sportowe itp. Wytwarzaja one więzi pomiędzy ich członkami oraz wpływaja na ich zachowania, od wewnatrz kształtujacc formy właściwe dla każdej $z$ tych form więzi. Tak rozumiana kultura samego społeczeństwa jest ujęta zarówno na sposób historyczno-opisowy, jak i normatywny. Kultura w wymiarze społecznym ma też pluralistyczny charakter, gdyż jej składowa stanowią kultury owych związków: Kościołów i wspomnianych wyżej rozmaitego rodzaju organizacji, w tym także instytucji nauczania na różnym poziomie, zwłaszcza zaś uniwersyteckim, towarzystw naukowych i tym podobnych zrzeszeń czy nawet mediów. Kulturę społeczna określić można również mianem kultury podłoża. Tworza ją bowiem Kościoły, uniwersytety i wiele związków niekoniecznie o charakterze obywatelskim. Ogólnie rzecz ujmujacc, kultura podłoża kształtuje sposób, w jaki system społeczny tworzy i odtwarza w czasie pewna formę kultury, w której wspólnie oczestniczą osoby mające określone koncepcje własnego dobra ${ }^{4}$. Niezwykle istotnym elementem dla kultury podłoża sa przekonania metafizyczne lub religijne, które ukazuja rozziew pomiędzy porządkiem idealnym a rzeczywistym, tym samym wywołując napięcie u członków organizacji wchodzacej w skład tej kultury. Napięcie to wywołuje dynamikę, której elementem staje się dążenie zrzeszonych $\mathrm{w}$ tej organizacji jednostek do przekształcania rzeczywistości w zgodzie $z$ wyidealizowana transcendentna wizja i wdrażanie elementów tej wizji do rzeczywistości ${ }^{5}$. W ten sposób elementy normatywne wpływają na dynamikę zmiany i pozwalaja - przynajmniej częściowo - wyjaśnić historyczną zmienność dóbr oraz praktyk.

Elementem europejskiej kultury społecznej jest także poziom kontestacji tradycyjnie przyjmowanych koncepcji metafizycznych.

\footnotetext{
4 J. Rawls: Liberalizm polityczny, przekład A. Romaniuk, Wydawnictwo Naukowe PWN, Warszawa 1998, s. 293.

5 S. Eisenstadt: Utopia i nowoczesność, przekład A. Ostolski, Oficyna Naukowa, Warszawa 2009, s. 263.
} 
Każde $z$ takich stanowisk bowiem spotyka się $z$ krytyką wewnętrzna i zewnętrzna innych członków kultury. Krytyka wewnętrzna polega na kontestacji dóbr oraz praktyk na podstawie alternatywnych elementów normatywnych, zawartych w tej samej doktrynie, krytyka zewnętrzna zaś - na odrzuceniu całego tego rodzaju stanowiska $z$ innej, zewnętrznej wobec niego perspektywy.

Zasadniczo jednak kultura społeczna jest skierowana na zewnątrz kultura sfery prywatnej. Omawiajac instytucje sfery społecznej, znany badacz tej problematyki, Jürgen Habermas wskazał, że przestrzeń ta miała charakter pośredni pomiędzy sfera intymną (zakryta, niejawna) a państwową (w pełni widoczna). Wraz $z$ rozwojem mieszczaństwa wzrosło znaczenie sfery prywatnej6. Przestrzeń prywatna $z$ kolei wyodrębniła dwie funkcje: chroniła intymność i zarazem stanowiła zalążek sfery społecznej, w takim zakresie, w jakim ludzie gotowi byli wchodzić $\mathrm{w}$ relacje $z$ innymi jednostkami tworzacymi społeczeństwo. W odniesieniu do tego, co wewnętrzne, intymności została przeciwstawiona niedyskrecja. W sferze społecznej zaś mogły się kształtować relacje oraz więzi. Ponadto składała się ona $z$ osób (choć początkowo nie obywateli) względnie równych między sobą i niezależnych ekonomicznie.

Po drugie, kultura ma wymiar publiczny, który wiąże się $z$ wejściem kultury społecznej w przestrzeń publiczną. Proces ten niejako zrównuje osoby, a dobra kulturowe staja się w tym obszarze pojmowania kultury mierzalne ilościowo. Kultura publiczna jest kultura wspólna w tym przynajmniej znaczeniu, że upublicznione elementy, jak przedmioty, interpretacje, wartości, praktyki, zaczynają tworzyć pewne uniwersum, które może być przedmiotem badań socjologicznych. W przestrzeni publicznej elementy kulturowe nie znikaja, ale nieco modyfikuja swój charakter. Odnosza się bowiem już nie do osób prywatnych, tworzących społeczeństwo, ale do obywateli, którzy dzielą status równego obywatelstwa ${ }^{7}$.

${ }_{6}$ J. Habermas: Społeczne struktury sfery publicznej, w: idem: Strukturalne przeobrażenia sfery publicznej, przekład W. Lipnik, M. Łukaszewicz, Wydawnictwo Naukowe PWN, Warszawa 2007, s. 124.

7 J. Rawls: Liberalizm polityczny, s. 293. 
Wyróżnikiem tego, co publiczne jest więc przede wszystkim równość. Ale można wskazać także na formę i jej publiczny, czyli „otwarty do wglądu”, charakter. Obywatele sami często podejmuja decyzję, jaki fragment ich postaw wymaga upublicznienia, czym chca dzielić się z innymi współobywatelami, a co wola pozostawić w sferze prywatnej. Na poziomie normatywnym, trwaja dyskusje na temat charakteru sfery publicznej oraz tego, jakie elementy postaw powinny zostać upublicznione, a jakie moga czy nawet powinny pozostać nieujawnione.

Po trzecie, kultura ma wymiar obywatelski, tzn. przenosi akcent $z$ różnych form aktywności kulturowych jednostek na wspólne dobra, praktyki oraz na zbiorowo realizowane przez obywateli cele określonej wspólnoty politycznej. O ile publiczny charakter kultury dotyczy szeregu związków i stowarzyszeń, o tyle kultura obywatelska zawęża swój przedmiot do jednostek, które wchodza $\mathrm{w}$ relację $z$ władza polityczna i wywieraja na nia rozmaity wpływ. Ponadto kultura obywatelska przenosi akcent $z$ różnic kulturowych pomiędzy równymi sobie obywatelami na wspólnotę polityczna i zbiorowo realizowane cele. „Kultura obywatelska” więc jest pojęciem węższym od pojęcia „kultury publicznej”, a szerszym od pojęcia „kultury politycznej”. Kultura obywatelska obejmuje różnorodne formy aktywności publicznej, takie jak np. działalność charytatywna i samopomocowa itp. Kulturę obywatelska wyznacza poziom kompetencji w sprawach publicznych, poszukiwanie pól kooperacji $z$ innymi.

O kulturze obywatelskiej pisze na przykład Robert Putnam w słynnej pracy, opartej na długoletnich badaniach demokracji we Włoszech. Stwierdza on, iż znaczenie relacji pomiędzy obywatelami dla procesu budowy kultury demokratycznej jest zasadnicze ${ }^{8}$. Ponadto autor ten podkreśla zwłaszcza skłonność do kooperacji pomiędzy obywatelami, którzy nawiązuja pomiędzy sobą bezpośrednie relacje i więzi, budując strukturę wzajemnego zaufania.

8 R. Putnam: Demokracja w działaniu. Tradycje obywatelskie we współczesnych Włoszech, przekład J. Szacki, Wydawnictwo Znak-Fundacja im. Stefana Batorego, Kraków-Warszawa 1995. 
Podkreślmy, struktura ta może być niezależna od światopoglądów czy przekonań natury metafizycznej. Jak czytamy: „Osobiste interakcje dostarczaja informacji o wiarygodności innych aktorów, co jest stosunkowo mało kosztowne i niezawodne. Jak przypomina nam ludowy teoremat $z$ teorii gier, istniejące zależności społeczne moga sprawić, że opłacalne będzie być godnym zaufania. Ponadto, kontynuowane zależności często zostaja wyposażone w społeczna treść, która każe wiązać wielkie oczekiwania $z$ zaufaniem i powstrzymywać się od oportunizmu [...] Dylematy więźnia sa [...] często omijane dzięki sile osobistych stosunków”.

Po czwarte, kultura ma wymiar także polityczny i wówczas odnosi się do przedstawicieli władzy, stosunków pomiędzy władzą a obywatelami, a także do historii instytucji władzy, konstytucji czy form ustrojowych.

W każdym $z$ wyżej wymienionych wymiarów można wyróżnić dwa rodzaje podejścia do kultury - opisowy oraz normatywny. Podejściem opisowym zajmują się socjologowie, opisując kulturę i jej przejawy. Drugim, czyli podejściem normatywnym do kultury politycznej, zajmuje się filozofia polityki, wyznaczając na przykład normatywne modele obywatelstwa bądź wzorce dla urzędników czy reprezentantów wspólnoty politycznej.

\section{Termin „kultura polityczna”}

Zestawienie pojęcia kultury z polityką ma długa tradycję. W 1916 roku prawnik Józef Siemieński podczas odczytu o Konstytucji 3 maja na Uniwersytecie Warszawskim stwierdził: „Kulturę polityczna należy rozumieć jako dorobek narodu $\mathrm{w}$ dziedzinie instytucji prawnoustrojowych"10. W sensie technicznym jednak, termin „kultura polityczna” został wprowadzony do obiegu naukowego dopiero

\footnotetext{
9 Ibidem, s. 268.

${ }^{10} \mathrm{~J}$. Siemieński: Kultura polityczna wieku XVI, w: Kultura staropolska, Polska Akademia Umiejętności, Kraków 1932, s. 121.
} 
przez Gabriela Almonda oraz Sidneya Verbę w latach sześćdziesiatych XX wieku.

Na kulturę polityczna składa się element kultury wysokiej, czyli pamięć polityczna, ujednolicona narracja, której przekazicielami sa członkowie elity określonej zbiorowości. Narracja ta nadaje związek wydarzeń historycznych $z$ określonymi emocjami zbiorowymi (afirmacja, neutralnością lub wyparciem) oraz ocenami (dobry, zły). Według Keitha Bakera kultura polityczna jest zbiorem dyskursów lub praktyk symbolicznych, przez które jednostki narzucaja sobie nawzajem konkurencyjne roszczenia ${ }^{11}$. Choć ten typ kultury politycznej można określić mianem kultury politycznej wysokiej, to trzeba mieć świadomość jej szerokiego oddziaływania. Kształtowane dzięki niej wyobrażenia oraz mity wykazują, zdaniem socjologów, zadziwiajaca trwałość ${ }^{12}$.

$\mathrm{Na}$ kulturę polityczna składa się także obywatelska kultura polityczna, która stała się bezpośrednim przedmiotem badań Almonda i Verby ${ }^{13}$. Obywatelska kultura polityczna to zbiór praktyk politycznych, które maja charakter wspólny, często nie sa przyjmowane świadomie, choć sa nośnikami wartości i nie muszą być opracowane dyskursywnie. Obywatelska kultura polityczna oznacza postawy obywatelskie wobec rzadzacych oraz poziom uczestnictwa obywateli w sprawowaniu władzy. Na postawy te składaja się: wiedza dotyczaca sposobu podejmowania decyzji politycznych oraz ich realizacji, zbiór emocji wobec rzeczywistości politycznej (pozytywnych bądź negatywnych), a także zbiór ocen ${ }^{14}$.

Należy także odróżnić kulturę polityczną obywateli od poziomu politycznych opinii. Opinie obywateli sa kształtowane przez prasę

\footnotetext{
${ }^{11} \mathrm{~K}$. Baker: Inventing the French Revolution. Essays on French Political Culture in the Eighteen Century, Cambridge University Press, Cambridge, NY 1990, s. 7.

${ }^{12}$ E. Wnuk-Lipiński, Socjologia życia publicznego, Wydawnictwo Naukowe Scholar, Warszawa 2008 , s. 167.

${ }^{13}$ G.A. Almond, S. Verba: The Civic Culture. Political Attitudes and Democracy in Five Nations, Little, Brown and Company, Boston 1965. Autorzy Ci przedmiotem swoich badań uczynili polityczny aspekt kultury obywatelskiej. $Z$ tego też powodu pojęcie „civic culture”, dla odróżnienia od późniejszych ujęć, w których kultura obywatelska może mieć pozapolityczny charakter zostało oddane jako obywatelska kultura polityczna.

${ }^{14}$ G.A. Almond, S. Verba: The Civic Culture, s. 14.
} 
i stanowia treść przestrzeni publicznej. Tendencje przemian opinii publicznej w długich okresach sa cennym źródłem danych empirycznych dla badaczy kultury politycznej, którzy na tej podstawie moga budować twierdzenia o kontynuacji bądź przemianach danych tendencji lub zjawisk politycznych ${ }^{15}$. Obywatelska kultura polityczna od opinii różni się jednak tym, że opinie są świadome i publiczne, podczas gdy kultura obywatelska zawiera także zbiór postaw i zachowań, które nie zawsze bywają uświadamiane, wyrażaja się natomiast w praktykach.

Ważnym elementem obywatelskiej kultury politycznej jest zakres decyzji podejmowanych wspólnie. Określa go wskazana już przez Almonda i Verbę dychotomia: liberalizm - statyzm. Liberalizm kładzie nacisk na dobro prywatne jednostek i akcentuje konieczność ograniczenia zakresu władzy do niezbędnego minimum ${ }^{16}$. Statyzm natomiast charakteryzuje się stawianiem tego, co wspólne, ale zarazem instytucjonalne i publiczno-polityczne przed tym, co indywidualne oraz prywatne i społeczne ${ }^{17}$.

Po takim zarysowaniu pola i dookreśleniu niejednoznacznego pojęcia „kultura” do znaczenia, jakie przybiera ono w odniesieniu do obywatelskiej kultury politycznej, można przejść do przedstawienia źródłowej dla tych badań metody. Metoda zastosowana do badania obywatelskiej kultury politycznej Almonda i Verby miała charakter historyczno-behawioralny. Historyczny składnik zastosowanej metody okazał się odpowiedni do śledzenia historycznego doświadczenia zbiorowości, odciskającego się w pamięci, uczuciach oraz oczekiwaniach tej zbiorowości, w tym także, w jakiej formie chce ona żyć, jakie elementy zbiorowości odpowiadaja za przenoszenie pamięci historycznej, oraz $z$ jaka intensywnościa pamięć ta jest przekazywana następnym pokoleniom ${ }^{18}$. Metoda historyczna posługuje się tekstami pisanymi, jako nośnikiem tej

\footnotetext{
${ }^{15}$ A. Jabłoński: Kultura polityczna i..., s. 179.

16 Ibidem, s. 182.

17 Ibidem.

${ }^{18}$ G.A. Almond, S. Verba: The Civic Culture, s. 39.
} 
pamięci, stara się odtworzyć ich znaczenie, zarówno w kontekście historycznym, jak i w przekazie kulturowym.

Jednocześnie do badania postaw politycznych Almond i Verba zastosowali metodę behawioralna. Polityczne postawy obywatelskie wyrażały się bowiem w zbiorze wspólnych praktyk politycznych członków poszczególnych społeczeństw, choć często praktyki te nie były przez nich sobie uświadamiane. Analiza dyskursu czy metoda historyczna nie byłyby w zwiazku $z$ tym przydatne do ich studiowania. Praktyki bowiem są nośnikami wartości, ale nie sa opracowane dyskursywnie. Można je badać przez obserwację zachowań, a więc metodę behawioralną. Obie metody więc, historyczna i behawioralna, miały charakter uzupełniajacy i pozostawały względem siebie komplementarne ${ }^{19}$.

Dla Almonda i Verby obywatelska kultura polityczna oznaczała szczególny zbiór orientacji wobec politycznych przedmiotów właściwy członkom danej zbiorowości. Na wymiar politycznej orientacji składały się wiedza o systemie politycznym jako całości, stosunek do podejmowanych decyzji politycznych oraz do efektów politycznych działań, a także zaangażowanie ${ }^{20}$. Na tej podstawie autorzy ci wyróżnili następujące typy obywatelskich kultur politycznych:

1. Kulturę zaściankową (nazywaną też tradycyjna), cechująca się brakiem wiedzy obywateli o systemie, a także brakiem ich stosunku do decyzji rządzacych oraz do efektów tych decyzji. Chodziło tu o ogólny brak zaangażowania obywateli w życie polityczne;

2. Kulture podporządkowania, w której wiedza obywateli o systemie była połaczona $z$ brakiem stosunku do podejmowanych przez władzę decyzji, a więc ich niezaangażowaniem, choć zarazem oczekiwaniem zmian;

3. Kulturę uczestnictwa, w której wiedza obywateli o systemie połaczona była $z$ określonym stosunkiem do decyzji politycznych i do ich efektów oraz $z$ zaangażowaniem ${ }^{21}$.

19 Ibidem.

${ }^{20}$ Ibidem, s. 15.

${ }^{21}$ Ibidem, s. 16. 
Jednocześnie wspomniani autorzy wskazali, że uczestnictwo w podejmowaniu decyzji politycznych może przybrać dwie skrajnie odmienne formy, jakimi sa totalitaryzm i demokracja. Demokracja umożliwia obywatelowi odgrywanie indywidualnej, aktywnej roli w procesie podejmowania decyzji politycznych, dając mu poczucie wpływu na nie. Totalitaryzm zaś aktywizuje obywateli jako uczestniczących członków ludu. Almond i Verba twierdza, iż pożądana $z$ perspektywy normatywnej demokratyczna forma uczestnictwa politycznego, wymaga odpowiedniej formy obywatelskiej kultury politycznej. Relacja pomiędzy struktura polityczna a kultura polityczna obywateli przesadza bowiem kwestię stabilności systemu.

Zdaniem autorów The Civic Culture przykładem demokratycznej obywatelskiej kultury politycznej jest kultura Wielkiej Brytanii. Jej specyfikę stanowi połączenie protestantyzmu (anglikanizmu) ze wzrostem znaczenia mieszczaństwa oraz włączeniem się arystokracji w handel. Zbieg tych okoliczności wytworzył kulturę pluralistyczna. Nie nastapiła dywersyfikacja i przeciwstawienie modernizmu tradycyjności, ale powstała spójna, pluralistyczna i choć zarazem jednolita obywatelska kultura polityczna ludu reprezentowanego przez parlament ${ }^{22}$. We Francji, Niemczech i we Włoszech zderzenie modernizmu $z$ tradycyjnościa nie pozwoliło na wyłonienie się wspólnej kultury politycznej, ale polegało na konfrontacji i politycznej walce pomiędzy subkulturami ${ }^{23}$. Celem tak normatywnie rozumianej obywatelskiej kultury politycznej, przesądzającej o trwałości instytucji demokratycznych, byłoby zatem hamowanie agresji politycznej.

Rozważania podjęte przez Almonda i Verbę były kontynuowane przez licznych badaczy i dotyczyły poszczególnych kultur, zwłaszcza zaś kultur narodowych. W Polsce tego typu analizy podejmowali socjologowie, a także publicyści oraz intelektualiści, komentujący dominujące postawy obywatelskie. W nurcie tym można

${ }^{22}$ Ibidem, s. 6.

${ }^{23}$ Ibidem, s. 7. 
na przykład odnaleźć wypowiedzi Jana Nowaka-Jeziorańskiego, który twierdził, że w Polsce brakuje mechanizmów hamujących agresję polityczną. Jego zdaniem, doszło do zderzenia modernizmu $z$ tradycyjności, co nie pozwoliło na wyłonienie wspólnej obywatelskiej kultury politycznej:

W Polsce nie ma dziś wspólnego i powszechnie przyjętego dekalogu życia publicznego i nie ma skutecznie działającej opinii publicznej. Jest chaos pojęć, który prowadzi do nihilizmu i zniechęca do udziału w życiu publicznym znaczną cześć społeczeństwa ${ }^{24}$.

Kulturę, jako sposób hamowania agresji, traktował także znany polski socjolog Edmund Wnuk-Lipiński. Jego zdaniem na wysoką kulturę obywatelska składa się społeczny zasób zaufania, norm i powiązań. Zasób ten wzajemnie się podtrzymuje, dzięki czemu kultura polityczna się wzmacnia. Wówczas wytwarza się pozytywny stan równowagi społecznej, odznaczający się wysokim poziomem współpracy między obywatelami określonej wspólnoty, dużym zaufaniem, regułą odwzajemniania uczynności, znacznym zaangażowaniem w życie społeczne. Może też zachodzić proces odwrotny, gdy wzajemny brak zaufania powoduje narastanie agresji politycznej.

O niskiej kulturze obywatelskiej mówi się wtedy, kiedy zaufanie do innych jest znikome, a tolerancja dla odmiennych racji - niezbyt wysoka, przeważa dążenie do realizacji interesów charakterystycznych dla danej grupy, bez względu na skutki dla większej społeczności. Na niska kulturę obywatelska składa się więc partykularyzm, wykorzystywanie innych i ucieczka w prywatność. Wszystko to może powodować stagnację społeczna i ekonomiczna, gdyż następuje maksymalizowanie korzyści kosztem otoczenia społecznego ${ }^{25}$.

\footnotetext{
${ }^{24}$ J. Nowak-Jeziorański: Stan umysłów, „Plus-Minus”, dodatek do „Rzeczpospolitej”, 16 sierpnia $1997 \mathrm{r}$.

${ }^{25}$ E. Wnuk-Lipiński: Socjologia życia publicznego, Wydawnictwo Naukowe Scholar, Warszawa 2008 , s. $160-162$.
} 


\section{Kultura obywatelska i społeczny kapital}

W latach osiemdziesiątych XX wieku ponownie zaczęto interesować się kultura polityczna. Tym razem jednak powiązano ja przede wszystkim $z$ warunkami sprzyjającymi rozwojowi na płaszczyźnie gospodarczej. Kluczowe $\mathrm{w}$ tym okresie stało się ukute przez Roberta Putnama pojęcie „kapitału społecznego"26. Wskazał on na obecność w społeczeństwie względnie trwałych orientacji kulturowych, które maja poważne konsekwencje polityczne i gospodarcze. Przedmiotem jego dociekań stała się przede wszystkim tak rozumiana „kultura obywatelska”, która ukazywała poziom osobistej aktywności oraz umiejętność współdziałania. Putnam zdefiniował pojęcie kapitału społecznego w następujący sposób: „Kapitał społeczny odnosi się tu do takich cech organizacji społeczeństwa, jak zaufanie, normy i powiązania, które moga zwiększyć sprawność społeczeństwa, ułatwiając skoordynowane działania. Tak jak i inne postaci kapitału, kapitał społeczny jest produktywny, umożliwia bowiem osiagnięcie pewnych celów, których nie dałoby się osiagnać, gdyby go zabrakło [...”"27. Okazało się, że zadowoleniu z życia politycznego i wzajemnemu zaufaniu towarzyszy większa stabilność instytucji demokratycznych oraz znacznie wyższy rozwój gospodarczy.

Do koncepcji kapitału społecznego Putnam doszedł, analizując reformy polityczne rządu włoskiego w latach siedemdziesitych. Wówczas bowiem wprowadzono nowe instytucje samorząu terytorialnego, które zaczęły działać na terenie całych Włoch w tym samym czasie. O ile jednak na północy ich działalność przyczyniła się do wzrostu gospodarczego, o tyle na południu te same instytucje polityczne i prawne niczego nie zmieniły. Ta sytuacja skłoniła Putnama do podjęcia badań dotyczących tego, jak instytucje poli-

\footnotetext{
${ }^{26}$ R.D. Putnam, R. Leonardi, R.Y. Nanetti, F. Pavoncello: Explaining Institutional Success. The Case of Italian Regional Government, „American Political Science Review” 1983, t. 77, nr 1, s. 55-74.

${ }^{27}$ R. Putnam: Demokracja $w$ działaniu, s. 258.
} 
tyczne przystosowuja się do społecznego otoczenia i w jaki sposób otoczenie to wpływa na możliwość wzrostu gospodarczego ${ }^{28}$.

W podobnym nurcie rozwijały się badania Roberta Ingleharta, który po przeprowadzeniu analiz wielu społeczeństw uprzemysłowionych, stwierdził, że kultura polityczna wpływa na wydajność gospodarcza i stabilność demokratyczną. Jednocześnie stwierdził też odwrotna zależność: wzrost zamożności społeczeństwa wpływał na przyjmowane postawy i dominujace systemy wartości. Proces ten Inglehart nazwał cichą rewolucją i skonstatował, że dokonujaca się $\mathrm{w}$ rozwiniętych społeczeństwach przemysłowych przemiana wartości dotyczyła szerokiego ich spektrum: wartości religijnych, rodzinnych, patriotycznych i politycznych itd. Zdaniem Ingleharta rozwój gospodarczy wiązał się $z$ odchodzeniem od religijnych i absolutnych norm społecznych w stronę racjonalności i tolerancji ${ }^{29}$.

\section{Ujęcie filozoficzne}

Pod koniec lat dziewięćdziesiąych po raz trzeci na nowo podjęto prace nad kultura polityczna. Tym razem zwrócono uwage nie na jej aspekt polityczny czy ekonomiczny, ale na znaczenie najszerszych przekonań jednostek, w tym także przekonań religijnych. Ta właśnie fala zainteresowania kultura polityczna miała swój wymiar filozoficznopolityczny, w którym wówczas zwrócono uwage na znaczenie postaw religijnych. Albowiem wbrew ustaleniom wcześniejszych badaczy (między innymi Igleharta) znaczenie religii w kulturze politycznej bynajmniej nie zanikało. Coraz mocniej w zwiazku z tym stawiano pytanie o możliwość wspólistnienia demokracji ze światopoglądami innymi niż doktryna liberalna ${ }^{30}$. Stąd postawiono sobie za cel nie tyle opisanie i zbadanie kultury

\footnotetext{
${ }^{28}$ R. Putnam: Demokracja $w$ działaniu, s. 7.

${ }^{29}$ R. Inglehart: Kultura a demokracja, w: L.E. Harrisom, S.P. Huntington (red.): Kultura ma znaczenie. Jak wartości wpływają na rozwój społeczeństw, przekład S. Dymczak, Wydawnictwo Zysk, Poznań 2000, s. 148.

${ }^{30}$ S.P. Huntington: Will More Countries Become Democratic?, „Political Science Quarterly” 1984 , t. 99 , s. $193-218$.
} 
politycznej, ile jej przekształcenie i wypracowanie nowych wzorców postaw obywatelskich $\mathrm{w}$ taki sposób, aby stało się możliwe poszerzenie demokracji liberalnej. $Z$ tej perspektywy w pojęciu „kultury politycznej” został uwypuklony element normatywny, skoncentrowano się bowiem nie na badaniu istniejacych kultur i dominujących w nich postaw, lecz na rozważaniach na temat tego, jakiego modelu kultury potrzebuje demokracja oraz w jaki sposób można radzić sobie $z$ doktrynami, które wydają się w być opozycji do liberalnej demokracji.

Na ów zwrot w badaniach nad kultura polityczna wpłynał głośny artykuł Samuela Huntingtona Zderzenie cywilizacji?, opublikowany w czasopiśmie „Foreign Affairs” w 1993 roku $^{31}$. W tekście tym Huntington postawił tezę, iż po zakończeniu zimnej wojny rywalizację pomiędzy Wschodem a Zachodem zastapił spór pomiędzy ludami o odmiennych kulturach. Wedle Huntingtona, różnice kulturowe miały swe źródło przede wszystkim w religii. $Z$ tego powodu, jego zdaniem, wierność wartościom politycznym jest niewystarczajacym spoiwem społecznym, gdyż są nim wartości kulturowe. Huntington prognozował przy tym schyłek potęgi Zachodu, choć miał on być, według niego, powolny i nieliniowy. Aby jednak owa tendencję zatrzymać, jego zdaniem, konieczna jest odnowa zarówno potencjału ekonomicznego i militarnego, jak i kulturowej tożsamości ${ }^{32}$.

Podobny zwrot w latach dziewięćdziesiątych dokonał się w myśli Johna Rawlsa, który od rozważań nad pojęciem sprawiedliwości jako fundamentu liberalno-demokratyczych instytucji, przeszedł do konstrukcji modelu kultury politycznej. Także inni współcześni mu badacze coraz częściej wskazywali, że kluczem do powstania instytucjonalnych form liberalnej demokracji powinno być wykształcenie właściwej dla tej formy ustrojowej kultury politycznej33.

\footnotetext{
${ }^{31}$ S. Huntington: The Clash of Civilizations?, „Foreign Affairs” 1993, t. 72, nr 3, s. 22-49.

${ }^{32}$ S. Huntington: Zderzenie cywilizacji i nowy kształt ładu światowego, przekład H. Jankowska, Wydawnictwo Literackie Muza, Warszawa 2001, s. 107 i nn.

${ }^{33} \mathrm{~W}$ nurt ten wpisały się także prace Charlesa Taylora oraz autorów związanych $z$ wydawanym od 1997 roku czasopismem „Public Culture”, takich jak: Jürgen Habermas, Dilip Gaonkar, Craig Calhoun.
} 
I o ile więc socjologowie mogli dalej badać istniejące kultury, o tyle filozofowie skoncentrowali się na konstruowaniu modelu dobrego obywatela.

John Rawls jest jednym $z$ najbardziej znanych filozofów politycznych XX wieku. W latach dziewięćdziesiatych filozof ten zbudował normatywny model kultury politycznej. Jego intelektualna droga rozpoczęła się w latach pięćdziesiątych, w czasach, gdy w Stanach Zjednoczonych toczyła się dyskusja pomiędzy zwolennikami marksizmu a liberałami ${ }^{34}$. Esej, będacy prezentacja głównych tez napisanej nieco później Teorii sprawiedliwości ${ }^{35}$, ukazał się w 1958 roku i był zatytułowany Sprawiedliwość jako bezstronnośćc ${ }^{36}$. Stanowił on prezentację idei sprawiedliwości jako bezstronności. Sprawiedliwość została w nim połączona $z$ wrażliwością na sytuację osób najsłabszych oraz kwestią redystrybucji dóbr. Jego zainteresowania kultura polityczną obudziły się w latach osiemdziesiatych i dziewięćdziesiatych ${ }^{37}$.

$\mathrm{Na}$ problematyce kultury politycznej Rawls skoncentrował się w latach dziewięćdziesiątych. W pracy zatytułowanej Liberalizm polityczny centralnym zagadnieniem uczynił kwestię postaw obywatelskich, kultury politycznej oraz znaczenie cnoty dla współczesnego liberalnego społeczeństwa. Pewien normatywny model kultury publicznej został przez niego określony mianem „rozumu publicznego". Po publikacji Liberalizmu politycznego filozof nadal zajmował się kultura polityczną. Artykul, w którym ponownie podjął tę kwestię, został dołączony do pracy zatytułowanej Prawo ludów ${ }^{38}$. Rawls

\footnotetext{
${ }^{34}$ J. Rawls urodził się 21 lutego 1921 roku w Baltimore w stanie Maryland (USA), zmarł 24 listopada 2002 roku w Lexington w stanie Massachusetts.

${ }_{35}$ Teoria sprawiedliwości (A Theory of Justice, 1971; wydanie polskie, 1994).

${ }^{36}$ Skrócona wersja tego tekstu (licząca mniej więcej połowę jego długości) została zaprezentowana na sympozjum w Amerykańskim Towarzystwie Filozoficznym. Oddział Wschodni 28 grudnia 1957 roku i pod tym samym tytułem, tj. Justice as Fairness, ukazała sie jako artykuł w: „The Journal of Philosophy” 1957, t. 54, nr 22, s. 653-662.

${ }_{37}$ Liberalizm polityczny (Political Liberalism, 1993, wydanie polskie 1998). Trzy pierwsze rozdziały tej pracy zostały zaprezentowane na Uniwersytecie Columbia w kwietniu 1980 roku, a we wrześniu ukazały pod tytułem Kantian Constructivism in Moral Theory w "The Journal of Philosophy" 1980, t. 77, nr 9, s. 515-572.

${ }^{38}$ Zob. J. Rawls: O idei publicznego rozumu raz jeszcze, w: idem: Prawo ludów, przekład M. Kozłowski, Fundacja Aletheia, Warszawa 2001. Pierwodruk tego eseju w oryginale znalazł
} 
rozróżnił w nim kulturę podłoża oraz kulturę publiczną. Zbudował także model sfery publicznej i wyznaczył granice pomiędzy tym, co społeczne a tym, co może zostać upublicznione. Argumenty $z$ kultury podłoża mogły, jego zdaniem, przedostawać się do kultury publicznej jedynie wówczas, gdy spełniały warunek upublicznienia, a więc dostarczały poza doktrynalnymi, także publicznych racji, wspierajacych proponowane rozwiazania.

Rawls uznał przy tym, że większość publicznej argumentacji była formułowana w obszarze kultury podłoża, czyli kultury Kościołów i stowarzyszeń rozmaitego rodzaju, instytucji nauczania na różnym poziomie (zwłaszcza zaś na poziomie uniwersyteckim), towarzystw naukowych i tym podobnych związków i stowarzyszeń oraz mediów. Filozof ten wprost stwierdził, że normatywnie rozumiana kultura polityczna, realizująca postulaty związane $z$ rozumem publicznym, nie stosowała się do kultury podłoża wraz z jej wieloma niepublicznymi rozumami ani do żadnego rodzaju mediów ${ }^{39}$. Wolna i pełna dyskusja w obrębie kultury podłoża była bowiem konieczna. W mediach prywatnych profil polityczny bywał określony przez warunki ekonomiczne, które miały wpływ także na kształtowanie agendy dyskutowanych problemów. Dyskusje te toczono także w mediach publicznych, na które również wpływały rozmaite elementy kultury podłoża. W takich okolicznościach Rawls pozwalał na wprowadzanie argumentów doktrynalnych zgodnie z zastrzeżeniem, żeby służyły wypracowaniu konsensusu.

Rawls rozróżnił w ten sposób ludzi jako obywateli i ich obywatelski punkt widzenia oraz ludzi jako członków rodzin i innych stowarzyszeń, przynależących do społecznej kultury podłoża. Poglądy pochodzące $z$ kultury podłoża mogły zostać wprowadzone do politycznej debaty $z$ zachowaniem, jak powiada Rawls, klauzuli, a więc wówczas, gdy spełniały warunek publiczności, czyli dostarczały także racji publicznych, wspierających proponowane

się w: „University of Chicago Law Review” 1997, t. 64, a następnie został włączony do Collected Papers opublikowanych przez Harvard University Press w roku 1999.

${ }^{39}$ J. Rawls: Prawo ludów, przekład M. Kozłowski, Fundacja Aletheia, Warszawa 2001, s. 192. 
rozwiązania. Celem były wspólne praktyki obywatelskie, częściowo oderwane od jakiejś określonej filozoficznej czy religijnej koncepcji dobra, wizji celu i sensu życia. I właśnie dlatego, że należały do obszaru praktyk, tzn. kultury, a nie dyskursu, dawały szansę na powszechna zgodę. Mogły bowiem poszukiwać swego uzasadnienia w rozmaitych doktrynach i teoriach. W każdej $z$ nich zasady liberalizmu politycznego znajdowały inne uzasadnienie, ale jednak każda doktryna, zdaniem Rawlsa, pozwalała na względnie niezależną debatę na temat wspólnotowych praktyk, które przynależały do obszaru kultury publicznej.

W ten sposób Rawls uznał, że liberalna demokracja nie wymaga określonych światopoglądów, może bowiem zostać urzeczywistniona także w społeczeństwach o nastawieniu religijnym. Zaplecze moralno-ideowe politycznego liberalizmu stanowi nie jakaś określona teoretyczna tradycja moralno-filozoficzna lub religijna, ale właśnie praktyczna tradycja życia demokratycznego znana i akceptowana przez ogół obywateli wychowanych w zachodniej demokracji. Obywatele ci znają i wspólnie akceptuja instytucje demokratycznego społeczeństwa oraz przyjęte sposoby rozumienia tych instytucji. Dzięki zastosowaniu narzędzi filozoficznych, Rawls wyabstrahował normatywny wzorzec obecny w tej kulturze i po opracowaniu określił go mianem „ideału ogłady”. Ideał taki nie tylko mógł zostać opisany, ale także potraktowany jako pozytywny wzorzec postaw obywatelskich, które winny być kształtowane $\mathrm{w}$ procesie edukacji.

W ten sposób studia nad kultura polityczna przybrały formę normatywnych rozważań, prowadzonych na gruncie filozofii polityki. Okazało się, że demokracja jako forma ustrojowa wyrasta $z$ tradycji zarówno ideowej, jak i politycznej Zachodu, ale jednocześnie wymaga ona określonego typu obywateli, którzy tę demokrację cenią i w swoim życiu zbiorowym urzeczywistniają. $Z$ rozważań tych płynał wniosek pesymistyczny: poza Zachodem nie ma obszaru, na którym ukształtowałyby się podobne instytucje, wyobrażenia i uzasadnienia. Na marginesie rozważań nad kultura polityczna 
pojawił się jednak także optymistyczny wniosek płynacy $z$ analizy prac filozofów polityki: na kulturę polityczna można wpływać przez edukację obywateli. W ten sposób historyczny proces, który tylko w ograniczonym zakresie doprowadził do ukształtowania się cenionych przez nas współcześnie form władzy, może i powinien zostać uzupełniony świadomym wysiłkiem, majacym na celu określenie pożądanego modelu obywatela i włączenie edukacji obywatelskiej $\mathrm{w}$ proces kształcenia. 